\title{
Use of Molecular Typing Methods To Trace the Dissemination of Listeria monocytogenes in a Shrimp Processing Plant
}

\author{
M. T. DESTRO,$^{1 *}$ M. F. F. LEITÃO,$^{2}$ AND J. M. FARBER ${ }^{1}$ \\ Health Canada, Banting Research Centre, Ottawa, Ontario, Canada K1A 0L2, ${ }^{1}$ and Seção de Microbiologia, \\ Instituto Tecnologia de Alimentos, 2880-13.073-330, Campinas, SP, Brazil ${ }^{2}$
}

Received 16 June 1995/Accepted 30 November 1995

\begin{abstract}
Molecular typing of bacteria has been widely used in epidemiological studies but not as extensively for tracing the transmission of pathogenic bacteria in food plants. This study was conducted to examine the potential use of two molecular typing methods, random amplified polymorphic DNA (RAPD) analysis and pulsed-field gel electrophoresis (PFGE), to trace Listeria monocytogenes contamination in a shrimp processing plant. Ribotyping and phage typing were also performed on a select number of strains. One hundred fifteen strains of $L$. monocytogenes collected in different areas of a shrimp processing plant were first serotyped and then subtyped by molecular typing. RAPD and PFGE showed great promise for typing $L$. monocytogenes isolates since distinguishable and reproducible DNA polymorphisms were obtained. When the composite profile from both (RAPD and PFGE) methods was generated, there was an increase in the discriminatory power to discern differences between strains of $L$. monocytogenes. The results indicated that environmental strains all fell into composite profile groupings unique to the environment, while strains from both water and utensils shared another composite profile group. L. monocytogenes fresh shrimp isolates belonging to one profile group were found in different areas of the processing line. This same profile group was also present in food handlers from the processing and packaging areas of the plant.
\end{abstract}

The importance of seafood in the spread of food-borne pathogens is well known (23); however, until the last few years, little attention has been paid to the role of seafood in disseminating Listeria monocytogenes. Two food-borne listeriosis outbreaks have been linked to the consumption of seafood (13, 21 ), and in three sporadic cases of listeriosis, the microorganism was identified as the causative agent. L. monocytogenes and other Listeria species have been isolated from different types of raw or processed seafood (7), but the main source of contamination is unknown. For this reason, it is important to monitor the potential sources of this pathogen in food processing plants to minimize product contamination.

Learning about the ecology and epidemiology of Listeria spp. can help to identify potential sources of contamination and to trace the spread of $L$. monocytogenes in food plants. However, traditional typing systems like biotyping and serotyping provide little information for epidemiological purposes (10). Phage typing is more sensitive (19), but not all Listeria isolates are typeable, and only few laboratories can perform phage typing routinely. Among human Brazilian isolates of $L$. monocytogenes examined over a 17 -year period, only $52 \%$ were phage typeable (22). Multilocus enzyme electrophoresis (1), DNA restriction enzyme analysis (30), and plasmid profile analysis (9) have also been evaluated. Comparing the electrophoretic mobilities of 16 enzymes allowed the clustering of clinical and food isolates of $L$. monocytogenes into two major electrophoretic typing groups (1). Some clinical and food strains from food-borne outbreaks of listeriosis were also compared by restriction endonuclease analysis, showing that isolates from each of the outbreaks exhibited a characteristic restriction pattern not shared with other strains (30). Plasmid

\footnotetext{
* Corresponding author. Present address: Depto. Alimentos e Nutrição Experimental, Fac. Ciências Farmacêuticas, USP, Av. Prof. Lineu Prestes, 580, Bl. 14-05.508-900, São Paulo, SP, Brazil. Phone: 55 11818 7991. Fax: 5511815 4410. Electronic mail address: mtdestro@ fox.cce.usp.br.
}

profile analysis could provide useful epidemiological information, but plasmid carriage by L. monocytogenes appears to be low (16), limiting the usefulness of plasmid typing for this organism.

Random amplified polymorphic DNA (RAPD) analysis and pulsed-field gel electrophoresis (PFGE) are two genotypic DNA typing methods that have been used successfully to characterize various microorganisms $(11,17,23,31-33)$, in addition to L. monocytogenes $(2,4,8,12,13,18,20,24)$. RAPD employs PCR to amplify genomic DNA segments with single primers of arbitrary nucleotide sequence (31). The amplified products are resolved by electrophoresis, and DNA polymorphisms are detected. By use of PFGE, large fragments (up to 2,000 kb) are generated by digesting DNA with low-frequency cutting restriction enzymes. These large fragments of genomic DNA can be resolved because of the repeated changes in the electric field orientation. Both methods, either alone or combined with other typing methods, have shown good discriminatory power, are easy to interpret, and have permitted subtyping of $L$. monocytogenes strains.

These methods have been used in epidemiologic studies (2, $12,24)$ for strain comparisons $(3,4,8,13,14,16,20-22)$. The present study was conducted to examine the potential use of RAPD and PFGE to trace L. monocytogenes contamination in a shrimp processing plant.

\section{MATERIALS AND METHODS}

Bacterial strains. The 115 L. monocytogenes strains used in this study are listed in Table 1. All were derived from samples collected in a shrimp processing plant in Santos, SP, Brazil, over a 5-month period (May to September 1993). Shrimp samples were collected as described by Warburton et al. (28). Environmental (nonproduct contact site) samples and utensils (direct product contact surfaces) were collected either by the swab or sponge contact method (27). Water and ice samples were assembled in sterile flasks $(500-\mathrm{ml}$ portions or equivalent) and neutralized with chlorine. Samples from food handlers were obtained by washing one hand of each employee with $0.85 \%$ saline in a sterile plastic bag. Samples were transported to the lab in insulated boxes and analyzed within $24 \mathrm{~h}$, as described by Warburton et al. (28). Of the 115 L. monocytogenes strains used in this study, 25 were isolated from the environment (floors, walls, and pipes, etc.), 
TABLE 1. Description of L. monocytogenes strains used for RAPD and PFGE analysis

\begin{tabular}{|c|c|}
\hline Strai & Is \\
\hline \multicolumn{2}{|c|}{ 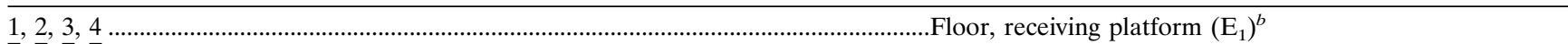 } \\
\hline \multirow{2}{*}{\multicolumn{2}{|c|}{ 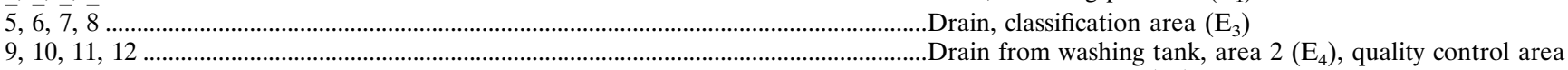 }} \\
\hline & \\
\hline \multicolumn{2}{|c|}{ 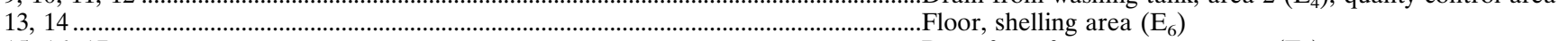 } \\
\hline \multicolumn{2}{|c|}{ 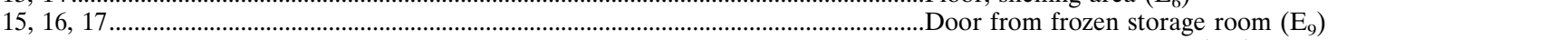 } \\
\hline \multicolumn{2}{|c|}{8 (1) } \\
\hline \multicolumn{2}{|c|}{ 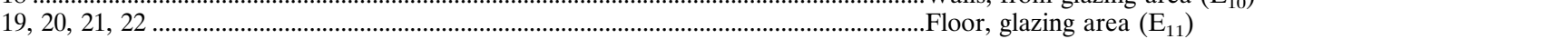 } \\
\hline \multicolumn{2}{|c|}{ 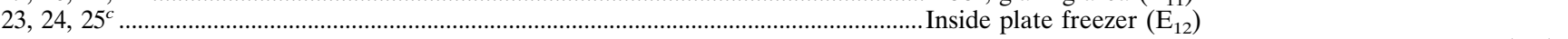 } \\
\hline \multicolumn{2}{|r|}{ (2) } \\
\hline \multicolumn{2}{|c|}{ 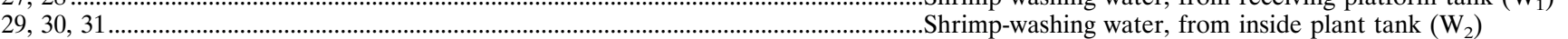 } \\
\hline \multicolumn{2}{|c|}{ 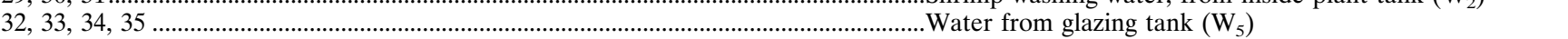 } \\
\hline \multicolumn{2}{|c|}{ 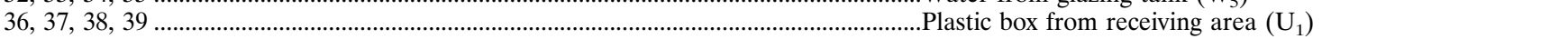 } \\
\hline \multicolumn{2}{|c|}{ 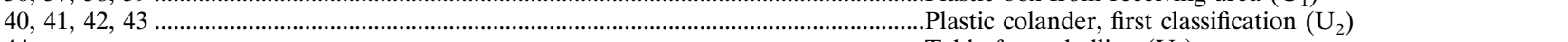 } \\
\hline \multicolumn{2}{|l|}{44 ................... } \\
\hline \multicolumn{2}{|c|}{ 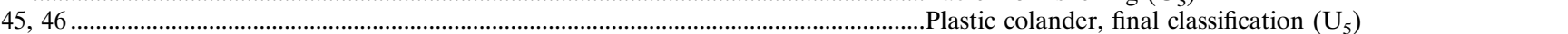 } \\
\hline \multicolumn{2}{|c|}{ 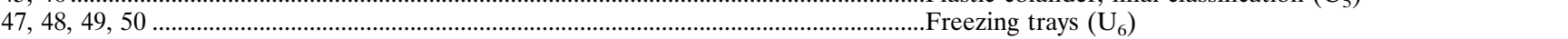 } \\
\hline \multicolumn{2}{|c|}{ 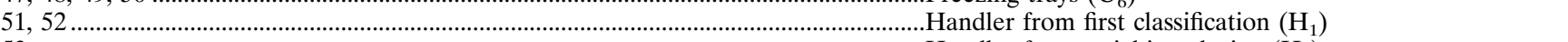 } \\
\hline \multicolumn{2}{|l|}{ 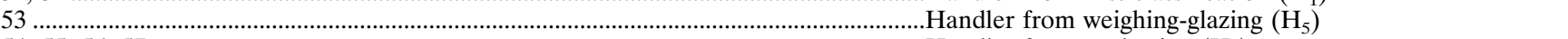 } \\
\hline \multicolumn{2}{|l|}{ 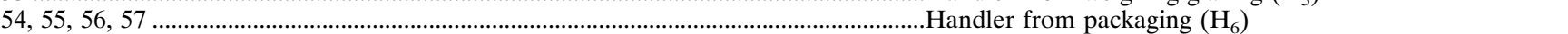 } \\
\hline \multicolumn{2}{|c|}{58} \\
\hline \multicolumn{2}{|c|}{ 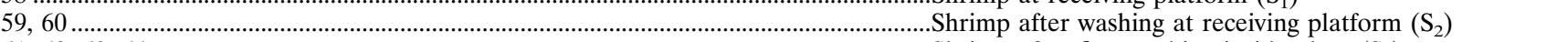 } \\
\hline \multicolumn{2}{|c|}{ 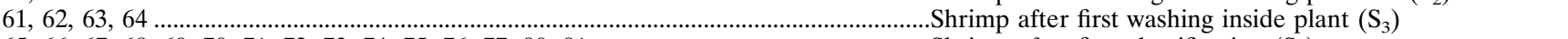 } \\
\hline \multicolumn{2}{|c|}{ 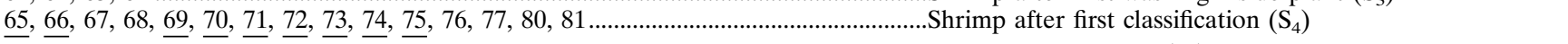 } \\
\hline 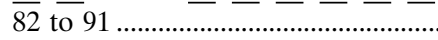 & ..................................................... \\
\hline \multirow{2}{*}{\multicolumn{2}{|c|}{92 to 100}} \\
\hline & \\
\hline & \\
\hline
\end{tabular}

${ }^{a}$ The multiple isolates listed were from multiple samples. Underlined numbers indicate serogroup 4 strains.

${ }^{b}$ The designation in parentheses is the location designation, with the subscript number representing the banding profile described in Fig. 1.

${ }^{c}$ Number 26 was omitted when numbering strains.

9 were isolated from water, 15 were isolated from utensils (knives, trays, and tables, etc.), 7 were isolated from shrimp handlers, and 59 were isolated from shrimp.

All strains were serotyped with Listeria $\mathrm{O}$ antisera types 1 and 4 (Difco) as described in the manufacturer's instructions. Selected strains were further serotyped by the Central Public Health Laboratory, Colindale, United Kingdom, by the method of Seeliger and Hohne (26).

Molecular typing. (i) RAPD. The Listeria strains were plated onto tryptose agar plates and grown at $30^{\circ} \mathrm{C}$ for $24 \mathrm{~h}$. A single colony was transferred to Trypticase soy broth containing $0.6 \%$ yeast extract (TSB-YE) and grown overnight at $37^{\circ} \mathrm{C}$. The cells were pelleted, resuspended in $1 \mathrm{ml}$ of saline $(0.85 \%$ $[\mathrm{wt} / \mathrm{vol}] \mathrm{NaCl}$ ), and transferred to sterile 1.5-ml Eppendorf tubes. The cell suspension was centrifuged for $5 \mathrm{~min}$ at $16,250 \times \mathrm{g}$, the supernatant was removed, and the pellet was resuspended in $500 \mu \mathrm{l}$ of sterile distilled water. Suspensions were diluted with water to an $A_{600}$ of 1.8 . The latter suspension, containing approximately $10^{7}$ cells per $\mu \mathrm{l}$, was used in the amplification reaction.

PCR mixtures contained $10 \mathrm{mM}$ Tris $\mathrm{HCl}(\mathrm{pH} 9.0), 50 \mathrm{mM} \mathrm{KCl}, 0.1 \%$ Triton X-100 (Promega, Madison, Wis.), $3 \mathrm{mM} \mathrm{MgCl}_{2}$ (Promega), $0.001 \%$ gelatin (Sigma Chemical Co., St. Louis, Mo.), $200 \mu \mathrm{M}$ each deoxynucleoside triphosphate (Pharmacia, Uppsala, Sweden), and $1 \mu \mathrm{M}$ random primer (UBC 155 [5'-CTG GCG GCT G-3'] and UBC 127 [5'-ATC TGG CAG C-3']; University of British Columbia, Vancouver, British Columbia, Canada). The mixture was UV treated for $20 \mathrm{~min}$ and aliquoted before primer and cells $(1 \mu \mathrm{l})$ were added. A negative control in which cells were replaced with $1 \mu l$ of sterile distilled water as well as a positive control in which cells were replaced with $1 \mu l$ of isolated Listeria DNA was included. The Eppendorf tubes were heated in a DNA Thermocycler GeneAmp PCR System (The Perkin-Elmer Corp., Norwalk, Conn.) at $96^{\circ} \mathrm{C}$ for $6 \mathrm{~min}$, and then $0.83 \mathrm{U}$ of $\mathrm{Taq}$ polymerase (Promega) was added. Reaction mixes were cycled through the following temperature profile: 1 cycle of $94^{\circ} \mathrm{C}$ for $2 \mathrm{~min} ; 35$ cycles of $94^{\circ} \mathrm{C}$ for $1 \mathrm{~min}, 35^{\circ} \mathrm{C}$ for $1 \mathrm{~min}$, and $72^{\circ} \mathrm{C}$ for $1.5 \mathrm{~min}$ (the ramp time between 72 and $94^{\circ} \mathrm{C}$ was $2 \mathrm{~min}$ ); and then 1 cycle at $72^{\circ} \mathrm{C}$ for 5 min. Samples were held at $4^{\circ} \mathrm{C}$ until application to the gels.

The amplified products were resolved by electrophoresis on $1.5 \%$ agarose gels in TBE buffer ( $89 \mathrm{mM}$ Tris base, $89 \mathrm{mM}$ boric acid, $2 \mathrm{mM}$ EDTA [pH 8.4]; Boehringer Mannheim Biochemicals, Indianapolis, Ind.) containing $0.5 \mu \mathrm{g}$ of ethidium bromide per $\mathrm{ml}(6)$. The gels were photographed under UV transillumination, and a 123-bp marker (Gibco BRL, Gaithersburg, Md.) was included as a molecular weight standard. Banding profiles were determined and arbitrarily numbered, and molecular weights were estimated by use of the DNA Tool Kit program (RamSoft, Hull, Quebec, Canada). The program DNASTAR was used to generate the schematic representation of the gels.
Each strain was tested at least four times with each of the primers, with the repetitions being carried out with cells grown and harvested on different days.

(ii) PFGE. The Listeria strains were streaked onto tryptose agar plates and grown at $30^{\circ} \mathrm{C}$ for $24 \mathrm{~h}$. One colony was transferred to TSB-YE and grown overnight at $37^{\circ} \mathrm{C}$. A $100-\mu$ l aliquot was spread onto a tryptose agar plate, which was incubated at $30^{\circ} \mathrm{C}$ for 18 to $24 \mathrm{~h}$. Growth was harvested with $1 \mathrm{ml}$ of TE buffer $(10 \mathrm{mM}$ Tris $\mathrm{HCl}$ [Boehringer Mannheim] and $1.0 \mathrm{mM}$ EDTA [Sigma; $\mathrm{pH}$ $8.0]$ ), and $200 \mu \mathrm{l}$ of this suspension was mixed with $800 \mu \mathrm{l}$ of $1 \%$ low-meltingpoint agarose (Bethesda Research Laboratories, Gaithersburg, Md.) in TE buffer. Approximately $100 \mu \mathrm{l}$ of this mixture was dispensed into plug molds. Agarose plugs were incubated in a lysis solution containing $0.25 \mathrm{M}$ EDTA [pH 8.0 ], $0.5 \% N$-laurosylsarcosine (Sigma), and $0.5 \mathrm{mg}$ of proteinase K (Boehringer Mannheim) per $\mathrm{ml}$ for 24 to $48 \mathrm{~h}$ at $50^{\circ} \mathrm{C}$. After deproteinization, the plugs were stored at $4^{\circ} \mathrm{C}$ in the same solution. After inactivation of proteinase $\mathrm{K}$ with $1 \mathrm{mM}$ phenylmethylsulfonyl fluoride (Gibco BRL) in TE buffer, the plugs were rinsed in TE buffer and then digested with $50 \mathrm{U}$ of ApaI and SmaI (Boehringer Mannheim) in $100 \mu \mathrm{l}$ of the respective buffer and at the temperature recommended by the manufacturer.

The high-molecular-weight restriction fragments generated were resolved with a CHEF-DRII pulsed-field electrophoresis system (Bio-Rad, Hercules, Calif.) in $1 \%$ agarose gel in TBE buffer $(45.0 \mathrm{mM}$ Tris base, $45.0 \mathrm{mM}$ boric acid, $1 \mathrm{mM}$ EDTA [pH 8.4; Boehringer Mannheim]). The initial and final pulse times, respectively, were 5.0 and $40.0 \mathrm{~s}$ for ApaI and 1.5 and $18.0 \mathrm{~s}$ for SmaI. The migration period was $21 \mathrm{~h}$ at $200 \mathrm{~V}$, with the buffer being kept at $12^{\circ} \mathrm{C}$. At the end of the run, the gels were immersed for $1 \mathrm{~h}$ in a $1-\mu \mathrm{g} / \mathrm{ml}$ ethidium bromide solution and then destained for $3 \mathrm{~h}$. The gels were photographed under UV transillumination, with the Marker I $\lambda$ ladder (Boehringer Mannheim) being used as a molecular weight standard. As for RAPD, banding profiles for PFGE were determined and arbitrarily numbered, and molecular weights were estimated with the DNA Tool Kit (RamSoft). Each strain was tested at least four times with each enzyme.

\section{RESULTS}

RAPD. The $115 \mathrm{~L}$. monocytogenes strains were subjected to RAPD with two random primers (UBC 155 and UBC 127). Primers 155 and 127 generated 11 and 16 different RAPD profiles, respectively. Approximately 7 to 17 distinct bands were observed with UBC primer 155, while UBC 127 produced 


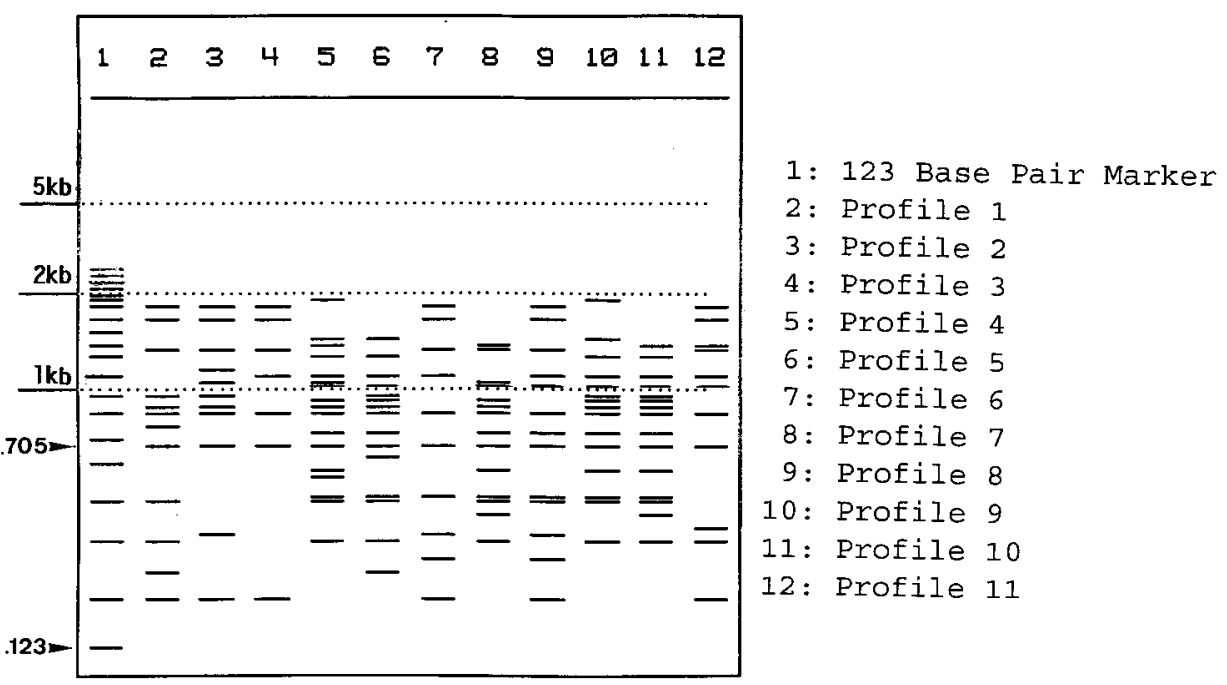

FIG. 1. Schematic representation of the 11 banding profiles of the L. monocytogenes isolates, obtained by RAPD with primer UBC 155.

a slightly higher number of bands ( 8 to 17 ), although some of them were very faint. The bands ranged in size from 246 to 1,845 bp for UBC 155 and from 246 to 3,296 bp for UBC 127 (results not shown).

The use of whole bacterial cells as a template for amplification gave very reproducible banding patterns. Running a positive control containing previously extracted DNA proved to be effective, while no amplification products were detected with the negative control (distilled water).

It is interesting to note that all 11 profiles generated by primer UBC 155 demonstrated bands of 705 and 861 bp (Fig. 1), while primer 127 did not generate any common bands. Four profiles were obtained with the 13 strains of serogroup 4 when primer UBC 155 was used, and nine profiles were obtained with the 102 strains of serogroup 1 . Two and seven unique profiles were obtained among serogroup 4 and serogroup 1 strains, respectively (Table 2). Profiles 3 and 11 were shared by strains of both serogroups.

Primer UBC 127 generated 5 profiles with the serogroup 4 strains and 12 profiles with the serogroup 1 strains. Four unique profiles were obtained with the serogroup 4 strains, while the strains of serogroup 1 fell into 11 unique profiles (Table 2). Profile 15 was common to both serogroups 1 and 4. Profiles 2 and 3 were very similar, with the latter not demonstrating the two bands of 537 and 1,290 bp.

Strains 1 and 2 appear to be very closely related genetically, both yielding a unique pattern with the two primers which was entirely different from that of the other strains. The same can also be inferred with strains 3 and 4, with strains 65, 66, 69, 70, 71 , and 72 , and with strains 73,75 , and 76 . Even though strains 73,75 , and 76 gave identical banding patterns by RAPD typing, they belonged to different serogroups (Table 2). Other strains which gave identical RAPD patterns with both primers were the following: 5 to $25 ; 27$ and $28 ; 30$ to $35,38,39,42,43$, and 47 to $50 ; 36,37,40,41$, and $44 ; 45$ and $46 ; 51$ to 58,63 , and 77 to $98 ; 59$ and $60 ; 61$ and $62 ; 67$ and 68 ; and 99 to 116 (Table 2). Strains 29 and 64 gave identical banding patterns with primer UBC 155 but different profiles with primer UBC 127. Strain 74 displayed the same banding profile as strains 73,75 , and 76 with primer UBC 155 but a different one with primer UBC 127.

PFGE. Visual comparison of macrorestriction patterns revealed 13 distinct $S m a$ I restriction endonuclease digestion pro- files (REDP) (Fig. 2) and 15 ApaI REDP for the 115 strains tested. When the DNA was digested with $S m a \mathrm{I}$, the number of bands ranged from 16 to 25 and band sizes ranged from 18.2 to $339.5 \mathrm{~kb}$. The most frequent REDP was number 5, with 62 of

TABLE 2. L. monocytogenes strain designations and RAPD and PFGE banding profiles

\begin{tabular}{|c|c|c|c|c|c|c|}
\hline \multirow{3}{*}{ Strain no. } & \multirow{3}{*}{$\begin{array}{l}\text { Serogroup } \\
\text { (serotype) }\end{array}$} & \multicolumn{4}{|c|}{ Banding profile designation } & \multirow{3}{*}{$\begin{array}{c}\text { Composite } \\
\text { profile }^{a}\end{array}$} \\
\hline & & \multicolumn{2}{|c|}{ RAPD } & \multicolumn{2}{|c|}{ PFGE } & \\
\hline & & UBC155 & UBC127 & Apa $\mathrm{I}$ & SmaI & \\
\hline 1,2 & $4(4 b)$ & 1 & 1 & 1 & 1 & A \\
\hline 3,4 & $4(4 b)$ & 2 & 2 & 2 & 1 & B \\
\hline 5 to 17,19 to 25 & 1 & 3 & 3 & 3 & 2 & $\mathrm{C}$ \\
\hline 18 & 1 & 3 & 3 & 4 & 3 & $\mathrm{D}$ \\
\hline 36,37 & 1 & 3 & 7 & 6 & 6 & $\mathrm{E}$ \\
\hline $40,41,44$ & 1 & 3 & 7 & 12 & 6 & $\mathrm{~F}$ \\
\hline $\begin{array}{l}65,66,69,70,71 \\
72\end{array}$ & $4(4 b)$ & 3 & 13 & 6 & 11 & G \\
\hline 29 & 1 & 5 & 5 & 3 & 5 & $\mathrm{H}$ \\
\hline $\begin{array}{l}30 \text { to } 35,38,39 \\
43,47 \text { to } 50\end{array}$ & 1 & 6 & 6 & 3 & 5 & I \\
\hline 99 to 116 & 1 & 8 & 6 & 3 & 5 & $\mathrm{~J}$ \\
\hline $\begin{array}{l}51,52,54 \text { to } 58 \\
63,77 \text { to } 86\end{array}$ & 1 & 8 & 9 & 3 & 5 & $\mathrm{~K}$ \\
\hline 53 & 1 & 8 & 9 & 9 & 5 & $\mathrm{~L}$ \\
\hline 87 to 94,96 to 98 & 1 & 8 & 9 & 15 & 5 & M \\
\hline 95 & 1 & 8 & 9 & 15 & 13 & $\mathrm{~N}$ \\
\hline 27,28 & 1 & 4 & 4 & 5 & 4 & $\mathrm{O}$ \\
\hline 64 & 1 & 5 & 12 & 11 & 10 & $\mathrm{P}$ \\
\hline 42 & 1 & 6 & 6 & 7 & 7 & Q \\
\hline 45,46 & 1 & 7 & 8 & 8 & 8 & $\mathrm{R}$ \\
\hline 67,68 & 1 & 10 & 14 & 8 & 8 & S \\
\hline 59,60 & 1 & 7 & 10 & 8 & 9 & $\mathrm{~T}$ \\
\hline 61,62 & 1 & 9 & 11 & 10 & 9 & $\mathrm{U}$ \\
\hline 73,75 & $4(4 b)$ & 11 & 15 & 13 & 12 & $\mathrm{~V}$ \\
\hline 76 & 1 & 11 & 15 & 14 & 12 & W \\
\hline 74 & $4(4 b)$ & 11 & 16 & 13 & 12 & $\mathrm{X}$ \\
\hline
\end{tabular}

${ }^{a}$ Each different set of banding profiles for both RAPD and PFGE was given an arbitrary number. The composite profile reflects the total differences or similarities in the banding patterns with the two RAPD primers and two PFGE enzymes. 

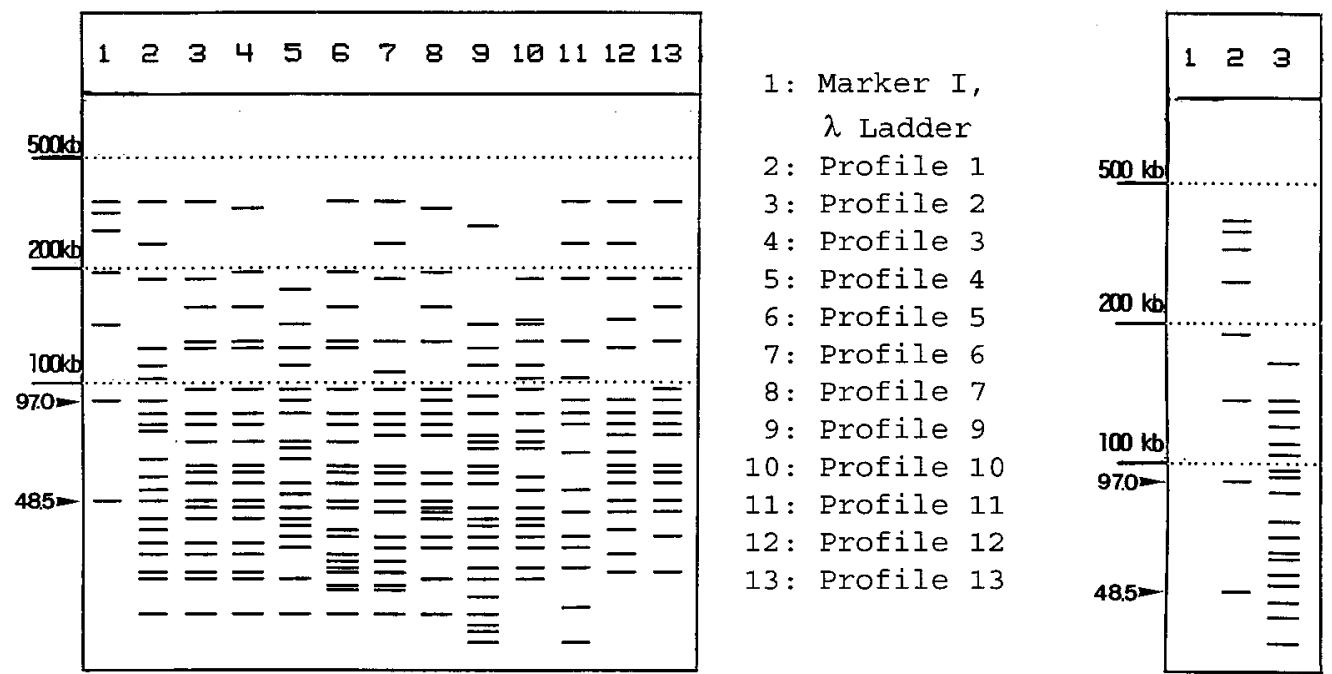

2: Marker I, $\lambda$ Ladder

3: Profile 8

2: Profile 1

3: Profile 2

4: Profile 3

5: Profile 4

6: Profile 5

7: Profile 6

8: Profile 7

9: Profile 9

10: Profile 10

11: Profile 11

12: Profile 12

13: Profile 13

FIG. 2. Schematic representation of the 13 profiles obtained after cleavage of genomic DNA of the L. monocytogenes isolates with SmaI.

the 115 strains belonging to it. The 13 strains of serogroup 4 displayed three REDP, two of them unique and one common to a serogroup 1 strain (Table 2). REDP 2 and 3 were very similar, both consisting of $20 \mathrm{SmaI}$ restriction fragments, 18 of them identical for both. ApaI-digested DNA generated REDP with a slightly lower number of bands (11 to 17$)$ and band sizes ranging from 20 to $557.2 \mathrm{~kb}$. Strains of serogroup 4 showed four unique REDP. The most common profile was REDP 3, comprising 70 of the 115 strains tested (Table 2).

A number of strains gave identical banding profiles with both enzymes, e.g., strains 1 and 2, strains 3 and 4, strains 5 to 17 and 19 to 25 , strains 65,66 , and 69 to 72 , and strains 73, 74, and 75. Of the isolates tested, strains 18, 42, and 64 each showed a unique REDP. Strain 53 fell into the most frequent SmaI REDP but showed a unique REDP when digested with ApaI. Strain 76 (serotype 1) had a SmaI REDP similar to that of strains of serogroup 4 but had a unique $A p a$ I REDP (Table 2). Strain 95 had an $A p a \mathrm{I}$ restriction pattern identical to those of strains 87 to 98 but a unique $S m a$ I restriction pattern.

After composite profiling (Table 2), the 115 strains of $L$. monocytogenes were divided into 24 groups. The 13 serotype $4 \mathrm{~b}$ strains were divided into five groups (A, B, G, V, and X), with group $G$ being the most common. Serotype $1 / 2 a$ and $1 / 2 b$ strains fell into five groups each, $\mathrm{O}, \mathrm{R}, \mathrm{S}, \mathrm{T}$, and $\mathrm{U}$ and $\mathrm{C}, \mathrm{F}$, $\mathrm{I}$, J, and $\mathrm{K}$, respectively (data not shown). The most frequently occurring composite profiles were $\mathrm{C}$, J, and $\mathrm{K}$, with 20,18 , and 18 strains belonging to each, respectively.

The shrimp processing plant was artificially divided into four distinct areas (Table 3) to facilitate comparisons among the different composite profile groups present. The four areas are designated as follows: area 1, receiving; area 2, washing; area 3, processing; and area 4, finished product. Table 4 shows the different composite profiles present in each area by sample type.

\section{DISCUSSION}

In this study, molecular typing was used as a tool to map the distribution of L. monocytogenes in a shrimp processing plant. RAPD and PFGE showed great promise in this regard for typing $L$. monocytogenes isolates, with distinguishable and reproducible DNA polymorphisms being obtained with both methods. The RAPD protocol using whole bacterial cells is simpler and faster than the one employing extracted DNA. However, when RAPD is used with whole bacterial cells, strict attention must be paid to the Taq polymerase concentration. In a previous study using extracted DNA as a template, Farber and Addison (8) obtained reproducible results when $0.5 \mathrm{U}$ of Promega Taq polymerase (per reaction) was used. In the present study, reproducible results were obtained after increasing the Promega Taq polymerase concentration to $0.83 \mathrm{U}$ per reaction.

Studies report the use of either RAPD $(5,8,13,14,16,18$, $21)$ or PFGE $(2,3,4,12,20,22,24)$ for typing $L$. monocytogenes. It can be noted that the number of profiles reported by different groups of researchers is extremely variable. Variations in primer sequences, source of reagents, equipment, and PCR programs for RAPD, choice of restriction enzymes, and geometry of the electric field as well as switching patterns during PFGE can be the cause of some of these variations. In addition, the lack of standardized criteria for evaluating the results makes the comparisons even more difficult.

Generally, the number of RAPD profiles obtained in our study was lower than those reported elsewhere $(8,13,14,18$, 21). However, the number of restriction patterns observed with PFGE corroborates previous findings $(2,4,22)$, except for the results reported by Brosch et al. (3), who found 72 and 63 unique profiles, using the enzymes $A p a \mathrm{I}$ and $A s c \mathrm{I}$, respectively, among 176 L. monocytogenes strains analyzed.

The use of both genotypic methods (RAPD and PFGE) for typing $L$. monocytogenes has not been reported. The combined profile generated when the two RAPD primers and the two PFGE enzymes were used increased the discriminatory ability to detect differences among strains of $L$. monocytogenes within serogroups. It was observed that there was some overlap among serogroups when only RAPD profiles were considered (Table 2). Finding similar RAPD profiles among strains from different serogroups has been reported previously $(8,13,14$, 21). However, when the composite RAPD-PFGE profile was generated, no overlap existed.

Within the four artificially divided areas of the shrimp processing plant (Table 3 ), only one of the five types of samples collected in one area belonged to the same profile group. On the other hand, the same sample type collected in different plant areas shared the same group profile. For example, profile 
TABLE 3. Shrimp processing plant flow chart, sampling points, and composite profile groups found at the various locations in the shrimp processing plant

\begin{tabular}{|c|c|c|c|}
\hline No. and type of area & Process flow chart & $\begin{array}{l}\text { Area or type } \\
\text { of sample } \\
\text { collected }^{a}\end{array}$ & $\begin{array}{l}\text { Composite profile groups } \\
\text { found at the various locations }\end{array}$ \\
\hline \multirow[t]{5}{*}{ 1-Receiving area } & Reception & $\mathrm{S}_{1}, \mathrm{E}_{1}$ & A, B \\
\hline & Washing & $\mathrm{W}_{1}$ & $\mathrm{O}$ \\
\hline & $\downarrow$ & $\mathrm{S}_{2}$ & $\mathrm{~T}$ \\
\hline & Selection & & \\
\hline & $\begin{array}{c}\downarrow \\
\text { Weighing }\end{array}$ & $\mathrm{U}_{1}$ & $\mathrm{E}, \mathrm{I}$ \\
\hline \multirow[t]{2}{*}{ 2-Washing area } & $\downarrow$ & & $\mathrm{C}, \mathrm{H}, \mathrm{I}, \mathrm{P}, \mathrm{U}$ \\
\hline & $\begin{array}{c}\text { Washing } \\
\downarrow\end{array}$ & $\begin{array}{l}\mathrm{W}_{2}, \mathrm{E}_{2} \\
\mathrm{~S}_{3}, \mathrm{E}_{4}\end{array}$ & \\
\hline \multirow[t]{8}{*}{ 3-Processing area } & Classification & $\mathrm{U}_{2}, \mathrm{H}_{1}, \mathrm{E}_{3}$ & $\mathrm{C}, \mathrm{F}, \mathrm{G}, \mathrm{K}, \mathrm{Q}, \mathrm{S}, \mathrm{V}, \mathrm{X}$ \\
\hline & $\begin{array}{c}\downarrow \\
\text { Shelling }\end{array}$ & $\mathrm{S}_{4}, \mathrm{E}_{5}$ & W \\
\hline & Shelling & $\begin{array}{l}\mathrm{U}_{3}, \mathrm{H}_{2} \\
\mathrm{~S}_{5}, \mathrm{E}_{6}\end{array}$ & $\mathrm{C}, \mathrm{F}, \mathrm{M}$ \\
\hline & Deveining & $\mathrm{W}_{3}, \mathrm{U}_{4}, \mathrm{H}_{3}, \mathrm{E}_{7}$ & $\mathrm{~J}, \mathrm{M}, \mathrm{N}$ \\
\hline & Washing & $\mathrm{W}_{4}$ & $\mathrm{~J}$ \\
\hline & $\downarrow$ & & \\
\hline & Classification & $\mathrm{U}_{5}, \mathrm{H}_{4}$ & $\mathrm{R}$ \\
\hline & Freezing (plate freezer) & $\mathrm{U}_{6}, \mathrm{E}_{12}$ & $\mathrm{C}$ \\
\hline \multirow[t]{7}{*}{ 4-Finished product area } & $\downarrow$ & & \\
\hline & Weighing & $\mathrm{H}_{5}$ & $\mathrm{~L}$ \\
\hline & Glazing & $\mathrm{W}_{5}, \mathrm{U}_{7}, \mathrm{E}_{10}$ & $\mathrm{D}, \mathrm{I}$ \\
\hline & $\downarrow$ & $\mathrm{E}_{11}$ & $\mathrm{C}$ \\
\hline & Packaging & $\mathrm{H}_{6}$ & $\mathrm{~K}$ \\
\hline & $\downarrow$ & $\mathrm{S}_{8}$ & $\mathrm{~J}$ \\
\hline & Storage & $\mathrm{E}_{9}$ & $\mathrm{C}$ \\
\hline
\end{tabular}

${ }^{a}$ See Table 1 for a more detailed explanation.

group C was found only in environmental samples from areas 2, 3, and 4 (strains 5 to 17 and 19 to 25). Therefore, it appears that composite profile $\mathrm{C}$ is part of the naturally occurring microflora occurring inside the plant, while group A (strains 1 and 2) and $\mathrm{B}$ (strains 3 and 4 ) are being introduced from outside the plant and remain restricted to the receiving area (area 1).

Although the water used in the plant was chlorinated and $L$. monocytogenes could not be isolated from samples collected from the main reservoir (data not shown), the microorganism

TABLE 4. Composite profile groups present in the different areas of a shrimp processing plant

\begin{tabular}{|c|c|c|c|c|c|}
\hline \multirow{2}{*}{ Sample type } & \multicolumn{4}{|c|}{ Profile group(s) in area no. } & \multirow{2}{*}{$\begin{array}{l}\text { Incidence of } \\
\text { L. monocytogenes } \\
\text { samples [no. } \\
\text { positive/total no. } \\
\text { of samples }(\%) \text { ] }\end{array}$} \\
\hline & 1-Receiving area & $\begin{array}{l}\text { 2-Quality control } \\
\text { (washing area) }\end{array}$ & 3-Processing area & 4-Finished product area & \\
\hline Environmental & $\mathrm{A}, \mathrm{B}\left(\mathrm{E}_{1}\right)^{a}$ & $\begin{array}{c}\mathrm{C}^{b}\left(\mathrm{E}_{3}+\mathrm{E}_{4}+\mathrm{E}_{6}+\right. \\
\left.\mathrm{E}_{9}+\mathrm{E}_{11}+\mathrm{E}_{12}\right)\end{array}$ & $\mathrm{C}^{b}(-)^{d}$ & $\mathrm{C}^{b}, \mathrm{D}\left[(-) ; \mathrm{E}_{10}\right]$ & $14 / 56(25)$ \\
\hline Water & $\mathrm{O}\left(\mathrm{W}_{1}\right)$ & $\mathrm{H}, \mathrm{I}^{b}\left[\mathrm{~W}_{2},(-)\right]$ & $\mathrm{ND}^{c}$ & $\mathrm{I}^{b}[(-)]$ & $5 / 21(23.8)$ \\
\hline Utensils & $\begin{array}{l}\mathrm{E}, \mathrm{I}^{b}\left(\mathrm{U}_{1}\right. \\
\left.\quad \mathrm{W}_{2}+\mathrm{W}_{5}+\mathrm{U}_{1}\right)\end{array}$ & & $\begin{array}{l}\mathrm{F}, \mathrm{Q}, \mathrm{I}^{b}, \mathrm{R}\left[\mathrm{U}_{2}+\mathrm{U}_{3} ; \mathrm{U}_{2}\right. \\
\left.\quad(-) ; \mathrm{U}_{5}\right]\end{array}$ & ND & $8 / 33(24.2)$ \\
\hline Shrimp & $\begin{array}{l}\mathrm{K}^{b}, \mathrm{~T}\left(\mathrm{H}_{1}+\mathrm{H}_{6}+\right. \\
\left.\quad \mathrm{S}_{1} ; \mathrm{S}_{2}\right)\end{array}$ & $\begin{array}{l}\mathrm{U}, \mathrm{K}^{b}, \mathrm{P}\left[\mathrm{S}_{3}\right. \\
\left.\quad(-) ; \mathrm{S}_{3}\right]\end{array}$ & $\begin{array}{c}\mathrm{G}, \mathrm{S}, \mathrm{V}, \mathrm{X}, \mathrm{W}, \mathrm{K}^{b}, \mathrm{M}, \mathrm{N}, \\
\mathrm{J}^{b}\left[\mathrm{G} \text { to } \mathrm{W} \rightarrow \mathrm{S}_{4} ;(-) ;\right. \\
\left.\mathrm{S}_{5}+\mathrm{S}_{6} ; \mathrm{S}_{6} ;(-)\right]\end{array}$ & $\mathrm{K}^{b}, \mathbf{J}^{b}\left[(-) ; \mathrm{S}_{6}, \mathrm{~S}_{7}, \mathrm{~S}_{8}\right]$ & $31 / 178(17.4)$ \\
\hline Food handler & ND & ND & $\mathrm{K}^{b}[(-)]$ & $\mathrm{K}^{b}, \mathrm{~L}\left[(-) ; \mathrm{H}_{5}\right]$ & $5 / 66(7.6)$ \\
\hline
\end{tabular}

${ }^{a}$ Designation(s) in parentheses indicates actual location in plant where strain of each profile group was isolated (see Table 1). In some instances, each profile group found matches up to one (e.g., area 2 for shrimp) or more (area 2, environmental) locations in the plant, while in other cases, two profile groups were found in the same location, e.g., see area 1, environmental. Otherwise, locations indicated in parentheses correlate with profile groups in respective order.

${ }^{b}$ Profile group was also found in other areas and/or sample types.

${ }^{c} \mathrm{ND}$, not detected.

${ }^{d}(-)$, location of this composite group is described in Table 3. 
was recovered from water used during processing. Group I strains were present in water collected in areas 2 (strains 30 and 31 ) and 4 (strains 32 to 35). The same group I strains were also isolated from plastic boxes taken from outside the plant (strains 38 and 39) as well as from utensils used in the processing area (strains 42, 43, and 47 to 50). The plastic boxes are used to transport raw shrimp from outside of the plant to the inside. It appears, therefore, that group I L. monocytogenes strains were transferred from the boxes to the washing water when the shrimp was loaded into the washing tank. After the shrimp were removed from this tank, carryover of water occurred, thus transferring $L$. monocytogenes to different utensils in the plant.

Some profile groups were exclusive to water isolates (group O, strains 27 and 28; group $\mathrm{H}$, strain 29) or to strains isolated from utensils (group E, strains 36 and 37; group Q, strain 42; and group R, strains 45 and 46). Group F strains were present on utensils sampled in two different locations in the processing area (location $\mathrm{U}_{2}$, strains 40 and 41 ; location $\mathrm{U}_{3}$, strain 44), i.e., a plastic colander and a table.

Some strains isolated from both shrimp and food handlers shared the same profile group, group $\mathrm{K}$. This group of isolates was isolated from shrimp in all four areas of the processing plant (Table 4) as well as from food handlers working in areas 3 (location $\mathrm{H}_{1}$, strains 51 and 52) and 4 (location $\mathrm{H}_{6}$, strains 54 to 57). The presence of group $\mathrm{K}$ strains in shrimp samples at the reception area could be due to natural product contamination or to contamination during storage in the ship. Food handlers probably got contaminated by $L$. monocytogenes group $\mathrm{K}$ after manipulating the shrimp. Employees tended to work in more than one area of the plant, which may explain the presence of group $\mathrm{K}$ strains on workers in both the processing and finished product areas. However, contrary to what was believed initially, food handlers did not appear to play a major role in the dissemination of $L$. monocytogenes throughout the plant, and the strains recovered from food handlers other than those in group $\mathrm{K}$ were not isolated from shrimp in the finished product area.

After being shelled, shrimp contained strains belonging to both groups $\mathrm{K}$ and $\mathrm{M}$ (location $\mathrm{S}_{5}$, strains 87 to 91 ). The latter strains were also found on shrimp during the next processing step, i.e., deveining (location $\mathrm{S}_{6}$, strains 92 to 94 and 96 to 98 ), but were not detected afterwards. This group may have contaminated the shrimp during the shelling or heading operations, when part of the intestinal contents are released.

Interestingly, only two profile groups (groups $\mathbf{J}$ and $\mathrm{K}$ ) were found on the frozen finished product even though nine different groups, including groups $\mathrm{J}$ and $\mathrm{K}$, were isolated from shrimp in the processing area (area 3 ). This could imply that some strains of $L$. monocytogenes may be better survivors than others, especially in terms of the organism's ability to withstand freezing. In addition, it was extremely interesting that none of the strains recovered from the environment, water, or utensils was also recovered from shrimp. This could signify that environmental strains may either be poor competitors or do not survive for long enough time periods in the environment to come into contact with the shrimp. The number of different strains of L. monocytogenes recovered from shrimp in the processing area (nine) was also remarkable. This contrasts with the number of strains recovered from other sample types, which ranged from two to five different strains recovered from food handlers and utensils, respectively. These differences in numbers of strains collected from various sample types may reflect a particular adaption of strains to a particular habitat or niche.

Since there were many different sources of $L$. monocytogenes in the shrimp processing plant, the elimination of L. monocytogenes from the frozen finished product would be a difficult, if not impossible, task, given the current state of plant hygiene. This is in line with current World Health Organization thinking that "the total elimination of L. monocytogenes from all food is impractical and may be impossible." Cleaning and sanitizing steps must be carried out effectively, and strict attention to hygiene must be observed all along the food chain, from the first few minutes out of the water to the final product, to avoid introducing L. monocytogenes into the plant and ultimately the product. However, the practical implications of this study are that both PFGE and RAPD can be used to track $L$. monocytogenes establishment and/or contamination in food processing plants. It is evident that development and use of the HACCP concept is urgently needed for all processing plants showing the degree and level of contamination observed in this study. In this regard, the two genotypic typing methods used in the current study can substantially aid food processors and regulators in establishing, controlling, and monitoring critical control points in the plant environment. This type of approach will likely become more important in the future as food safety concerns increase in food processing and distribution systems.

\section{ACKNOWLEDGMENTS}

We thank J. McLauchlin for serotyping the strains as well as M. Landgraf for stimulating discussions and E. Daley for technical assistance.

The stay of M. T. Destro in Canada was supported by a fellowship from Conselho Nacional de Desenvolvimento Cientifico e Tecnologico (proc. 201677/93.8), Brasilia, Brazil.

\section{REFERENCES}

1. Bibb, W. F., B. G. Gellin, R. Weaver, B. Schwartz, B. D. Plikaytis, M. W Reeves, R. W. Pinner, and C. V. Broome. 1990. Analysis of clinical and food-borne isolates of Listeria monocytogenes in the United States by multilocus enzyme electrophoresis and application of the method to epidemiologic investigations. Appl. Environ. Microbiol. 56:2133-2141.

2. Brosch, R., C. Buchrieser, B. Sixl-Voigt, and J. Rocourt. 1991. Use of pulsed field electrophoresis of DNA restriction fragments for comparing Listeria monocytogenes strains isolated from human infections and food in Austria. Zentralbl. Bakteriol. 275:557-560.

3. Brosch, R., J. Chen, and J. B. Luchansky. 1994. Pulsed-field fingerprinting of listeriae: identification of genomic divisions for Listeria monocytogenes and their correlation with serovar. Appl. Environ. Microbiol. 60:2584-2592.

4. Buchrieser, C., R. Brosch, B. Catimel, and J. Rocourt. 1993. Pulsed-field gel electrophoresis applied for comparing Listeria monocytogenes strains involved in outbreaks. Can. J. Microbiol. 39:395-401.

5. Czajka, J., N. Bsat, M. Piani, W. Russ, K. Sultana, M. Wiedmann, R. Whitaker, and C. A. Batt. 1993. Differentiation of Listeria monocytogenes and Listeria innocua by $16 \mathrm{~S}$ rRNA genes and intraspecies discrimination of Listeria monocytogenes strains by random amplified polymorphic DNA polymorphisms. Appl. Environ. Microbiol. 59:304-308.

6. Dillon, J.-A. R., G. S. Bezanson, and K.-H. Yeung. 1985. Basic techniques, p 27-30. In J.-A. R. Dillon, A. Nasim, and E. R. Nestmann (ed.), Recombinant DNA methodology. John Wiley \& Sons, Inc., New York.

7. Embarek, P. K. B. 1994. Presence, detection and growth of Listeria monocytogenes in seafood-a review. Int. J. Food Microbiol. 23:17-34.

8. Farber, J. M., and C. J. Addison. 1994. RAPD typing for distinguishing species and strains in the genus Listeria. J. Appl. Bacteriol. 77:242-250.

9. Fistrovici, E., and D. L. Collins-Thompson. 1990. Use of plasmid profiles and restriction endonuclease digest in environmental studies of Listeria spp. from raw milk. Int. J. Food Microbiol. 10:43-50.

10. Fuchs, R. S., and P. J. A. Reilly. 1992. The incidence and significance of Listeria monocytogenes in seafoods, p. 217-229. In H. H. Huss, M. Jakobsen, and J. Liston (ed.), Quality assurance in the fish industry. Proceedings of the International Conference 26-30 August 1991, Copenhagen. Elsevier, Amsterdam.

11. Haynes, K. A., D. J. Sullivan, D. C. Coleman, J. C. K. Clarke, R. Emilianus, C. Atkinson, and K. J. Cann. 1995. Involvement of multiple Cryptococcus neoformans strains in a single episode of cryptococcosis and reinfection with novel strains in recurrent infection demonstrated by random amplification of polymorphic DNA and DNA fingerprinting. J. Clin. Microbiol. 33:99-102.

12. Jacquet, C., B. Catimel, R. Brosch, C. Buchrieser, P. Dehaumont, V. Goulet, A. Lepoutre, P. Veit, and J. Rocourt. 1995. Investigations related to the 
epidemic strain involved in the French listeriosis outbreak in 1992. Appl. Environ. Microbiol. 61:2242-2246.

13. Kerr, K. G., P. Kite, J. Heritage, and P. M. Hawkey. 1995. Typing of epidemiologically associated environmental and clinical strains of Listeria monocytogenes by random amplification of polymorphic DNA. J. Food Prot. 58:609-613.

14. Lawrence, L. M., J. Harvey, and A. Gilmour. 1993. Development of a random amplification of polymorphic DNA typing method for Listeria monocytogenes. Appl. Environ. Microbiol. 59:3117-3119.

15. Lennon, D., B. Lewis, C. Mantell, D. Becroft, B. Dove, K. Farmer, S. Tonkin, N. Yeates, R. Stamp, and K. Mickleson. 1984. Epidemic perinatal listeriosis. Pediatr. Infect. Dis. 3:30-34.

16. MacGowan, A. P., K. O'Donaghue, S. Nicholls, J. McLauchlin, P. M. Bennett, and D. S. Reeves. 1993. Typing of Listeria spp. by random amplified polymorphic DNA (RAPD) analysis. J. Med. Microbiol. 38:322-327.

17. Mahalingam, S., Y. M. Cheong, S. Kan, R. M. Yassin, J. Vadivelu, and T. Pang. 1994. Molecular epidemiologic analysis of Vibrio cholerae O1 isolates by pulsed-field gel electrophoresis. J. Clin. Microbiol. 32:2975-2979.

18. Mazurier, S. I., A. Audurier, N. Marquet-Van der Mee, S. Notermans, and K. Wernars. 1992. A comparative study of randomly amplified polymorphic DNA analysis and conventional phage-typing for epidemiological studies of Listeria monocytogenes isolates. Res. Microbiol. 143:507-512.

19. McLauchlin, J., A. Audurier, and A. G. Taylor. 1986. The evaluation of a phage-typing system for Listeria monocytogenes for use in epidemiological studies. J. Med. Microbiol. 22:357-365.

20. Moore, M. A., and A. R. Datta. 1994. DNA fingerprinting of Listeria monocytogenes strains by pulsed-field gel electrophoresis. Food Microbiol. 11:3138.

21. Niederhauser, C., C. Höfelein, M. Allmann, P. Burkhalter, J. Lüthy, and U. Candrian. 1994. Random amplification of polymorphic bacterial DNA: evaluation of 11 oligonucleotides and application to food contaminated with Listeria monocytogenes. J. Appl. Bacteriol. 77:574-582.

22. Pereira, M. L., C. Buchrieser, R. Brosch, B. Catimel, J. Rocourt, and E. Hofer. 1994. Characterization of Brazilian Listeria monocytogenes strains using DNA macrorestriction patterns. Rev. Microbiol. 25:144-148.

23. Powell, N. G., E. J. Threlfall, H. Chart, and B. Rowe. 1994. Subdivision of
Salmonella enteritidis PT4 by pulsed-field gel electrophoresis: potential for epidemiological surveillance. FEMS Microbiol. Lett. 119:193-198.

24. Proctor, M. E., R. Brosch, J. W. Mellen, L. A. Garret, C. W. Kaspar, and J. B. Luchansky. 1995. Use of pulsed-field gel electrophoresis to link sporadic cases of invasive listeriosis with recalled chocolate milk. Appl. Environ. Microbiol. 61:3177-3179.

25. Riedo, F. X., R. W. Pinner, M. Tosca, M. L. Cartter, L. M. Graves, M. W Reaves, R. E. Weaver, B. D. Plikaytis, and C. V. Broome. 1994. A pointsource foodborne listeriosis outbreak: documented incubation period and possible mild illness. J. Infect. Dis. 170:693-696.

26. Seeliger, H. P. R., and K. Hohne. 1979. Serotyping of Listeria monocytogenes and related species, p. 31-49. In T. Bergan and J. R. Morris (ed.), Methods in microbiology, vol. 13. Academic Press, Inc., New York.

27. Sveum, W. H., L. J. Moberg, R. A. Rude, and J. F. Frank. 1992. Microbiologicla monitoring of the food processing environment, p. 51-74. In C. Vanderzant and D. F. Splittstoesser (ed.), Compendium of methods for the microbiological examination of foods, 3rd ed. American Public Health Association, Washington, D.C.

28. Warburton, D. W., J. M. Farber, and T. Babiuk. 1994. MF-HPB 30. Isolation of Listeria monocytogenes from all foods and environmental samples. In Compendium of analytical methods, vol. 2. Polyscience Publications, Morin Heights, Quebec, Canada.

29. Ward, D. R., and C. R. Hackney (ed.). 1991. Microbiology of marine food products. AVI Publishing Co., New York.

30. Wesley, I. V., and F. Ashton. 1991. Restriction enzyme analysis of Listeria monocytogenes strains associated with food-borne epidemics. Appl. Environ. Microbiol. 57:969-975.

31. Williams, J. G. K., A. R. Kubelik, K. J. Livak, J. A. Rafalski, and S. V. Tingey. 1990. DNA polymorphisms amplified by arbitrary primers are useful as genetic markers. Nucleic Acids Res. 18:6531-6535.

32. Yan, W., N. Chang, and D. E. Taylor. 1991. Pulsed-field gel electrophoresis of Campylobacter jejuni and Campylobacter coli genomic DNA and its epidemiologic application. J. Infect. Dis. 163:1068-1072.

33. Young, K. A., E. G. M. Power, M. S. Dryden, and I. Phillips. 1994. RAPD typing of clinical isolates of Staphylococcus haemolyticus. Lett. Appl. Microbiol. 18:86-89. 